\title{
MIGRATION CHALLENGES TO COMMON EUROPEAN IDENTITY: BETWEEN MYTHS AND REALITY
}

\author{
Petriaiev O. S., \\ Teacher of the Department of Theory and Practice of Management \\ National Technical University of Ukraine \\ "Igor Sikorsky Kiev Polytechnic Institute"
}

The article discusses attempts to create European identity and the threats posed by Muslim migration from the Middle East and the African continent. The system of building national identity and ideological base for uniting people and creating a nation is analyzed. Article conducts comparative analysis of the construction of national identity in Europe, in different periods of history. The system of building national identity in Italy, Germany and the Soviet Union is analyzed. The article analyzes the current weakness of European identity, which is threatened by Muslim expansionism in Europe and European nationalism.

У статті розглядаються спроби створення спільної європейської ідентичності і загрози та виклики цьому проектові, які виходять, зокрема, від мусульманської міграції з регіонів Близького Сходу і Африканського континенту. Аналізуються системні підходи до побудови національної ідентичності та ідеологічної бази для об'єднання європейських народів і створення європейської політичної нації. Здійснено порівняльний аналіз вдалих та невдалих спроб побудови спільної наднаціональної та національних ідентичностей в Європі у різні історичні періоди ії розвитку. Аналізується система побудови національної ідентичності в Італії, Германії та Радянському Союзі. Аналізується нинішня слабкість спільноєвропейської ідентичності, яку посилюють радикальний мусульманський експансіонізм, з одного боку, та європейський націоналізм, з іншого.

В статье рассматриваются попытки создания Европейской идентичности и угрозы, исходящие от мусульманской миграции из региона Ближнего Востока и Африканского континента. Анализируется система построения национальной идентичности и идеологической базы для объединения народов и создания нации. Проведен сравнительный анализ построения национальной идентичности в Европе в разные периоды истории. Анализируется система построения национальной идентичности в Италии, Германии и Советском Союзе. В статье проведен анализ нынешней слабости Европейской идентичности, которой угрожают мусульманский экспансионизм в Европе и Европейский национализм.

Key words: European Union, European identity, Muslim threat, migration, nationalism.

The general essence of the problem. The European Union is currently experiencing one of the worst crises, which can permanently change the further development of European countries under the influence of external factors in the form of an uncontrolled flow of refugees and migrants from Arab countries and Africa. The European society was not ready for such challenges and social changes. The central authority of the European Union is very slowly solving the problem of Muslim refugees. Nationalist movements in different European countries such as in Germany, France have felt the opportunity to come to power, offering radical solutions to the problem. While European nations are beginning to show disintegration tendencies, Muslim settlers begin to unite based on Islamic identity but do not assimilate the norms and rules of European civilization based on Christian values. There is a correlation between the separation of European nations, and its segmentation according to various factors, while the Muslim inhabitants of Europe are beginning to show signs of unification.

Analysis of recent research and publications. The theme of Muslim migration to Europe is very popular among scholars and writers. This issue became more popular after the beginning of the mass resettlement of Syrian refugees in 2015. It is important to note that the problem of Muslims in Europe is a question of the ethno cultural confrontation of Islam and Christianity, the south and the north. One of the first scientists who raised the issue, the collision of different cultures and civilizations was an American scientist Samuel P. Hungtington who, after the end of ideological confrontation during the Cold War, in his article and later in his book "The Clash of Civilizations", described the 
conflict between different civilizations. He also described the conflict between the European-Christian civilization and the Muslim world [1].

Russian scientists Bibikova O., Oleinik V., Razlivaev A., in their articles, give a general assessment of the situation with Muslim refugees in Europe [2], [3], [4]. They note that the main cause of instability in the Middle East and North Africa was the manipulative policy of the United States and the European Union, which put the Arab countries in a series of revolutions and civil wars. Also, Russian scientists are talking about a planned action to move refugees from the South to Europe and about dramatic consequences for the European Union. Among the Russian scientists describing this topic can be noted Olga Bibikova, which describes the overall situation as a whole.

In the western researches the subject of Muslim refugees in the European Union is addressed by both individual scholars and European scientific institutions. Among Western scientists describing the problems of Arab refugees in the European Union can be mentioned Maxime H.A. Larive, Elizabeth Collet and Camille Le Coz [5], [6].

Formulating the purpose of the article. The goal of the study is to trace the correlation between the increase in Muslim population in the European Union after the Arab Spring and the Arab refugee crisis in 2015, and the development of nationalist movements in Europe contributing to the disintegration of the European Union. Also, an analysis of the construction of the Arab-African nation is being carried out on the basis of religious cohesion and the division of the European peoples by ethnic, religious, and national characteristics.

Main Material. Today, the European Union (EU) is going through a series of different crises. One of these crises is caused by the influx of Arab and African refugees fleeing from poverty, political crises and war in their countries, and seeking a better life in the countries of the EU. New arrivals are united by a very important factor, this is their religion, Islam, and the concept of ummah, the philosophical and religious idea, which unites all devout Muslims, regardless of their ethnic origin, nationality, gender, or language of communication. Thus, the ummah (أمة), which translated from Arabic means a nation, is a connecting element that allows uniting all Muslims into one big nation [7].

Muslim migrants, who came to Europe with their religion, cultural practices and language, engage into conflict with the European society, which took shape over many centuries of European continent history. Thus, as American scientist Samuel Huntington would say, we are witnessing a "clash of civilization". European civilization, or, in particular, the EU confederation, is not itself a mono-ethical union, but an association of different European states, which themselves consist of different ethnic groups differing in ethnic, cultural, linguistic and religious factors. At different epochs of the development of Europe, the people were united into countries that later merged into the European Union, but at the same time the highest identity superstructure "European" was completely unable to take root in the identity of the people of the EU. From this it follows that the religious-philosophical and political concept of the Muslim nation or ummah plays as a destructive factor for the identity of European people.

\section{The Nation building in premodern and modern Europe}

The first thing to start with, is to give a definition of what a person's national identity is. The identity of a person is self-awareness, that is, giving oneself some distinctive signs to oneself in relation to "others," on which one's identity is built. That is, it is self-awareness and opposition, of identity with respect to society or "others". Cultural identity can be divided into granted and gained. Granted identity is acquired at birth, inspired by family, social environment, religion and cultural customs. The gained identity can be acquired by free choice, that is, elect by oneself.

Important element in building national identity is "one language, one culture, one history", which were formulated during the French Revolution. The French Revolution played a significant role in the formation of nations in the modern concept of the word, and had a great influence on Germany, Italy, Spain and Russia.

Identity forms a nation. As mentioned earlier, the concept of a nation was formed during the French Revolution in the 18th century. From the French language the word (nation) is also interpreted as (Groupement de personnes vivant dans un même pays et partageant la même culture, les mêmes traditions) which is translated in to English as "Group of people living in the same country and sharing the same culture, the same traditions" [8].

In the modern concept, nationality is understood as citizenship, and in democratic states, nationality does not depend on ethnic origin. Also, the nation has a second meaning, it is an ethno-political group that wants to have its own government and territory under its control, or it already has it. In the work of the British historian Eric Hobsbaum "Nations and Nationalism after 1780" the concept of a nation became widespread in Europe in the second half of the 19th century and the first half of the 20th century, after which it became spread to other continents. Thus, different nations may unite in different international unions, or enter into conflict when one of the nations or ethnic group wishes to withdraw from this union [9].

The nation state has become historically shaped in Europe. After the Thirty Years War and the Treaty of Westphalia, sovereign nation states began to appear in Europe. Thus, self-identification with this state is 
formed among the population living on the territory of the country, and submitting to its state. In the modern state, there are clearly defined borders of the territory, centralized power, can use the system of suppression within the state and is recognized by the world community. Over time, the population developed loyalty, patriotic feelings and self-identification with their state. It is also important to note that until the Thirty Years War, Europe was guided by universal religious values that were leveled in the era of reformation and religious wars. In the 19th century, each state had its own state ideology, which is instilled in the population, and national interests, which are defended either by the government of the state or in cases of war mobilized by the population.

Also, some states began to expand, by conquering, or uniting with other countries on a voluntary basis. History knows a lot of such examples.

The most important thing in uniting territories with a similar people, one language, is the creation of a common identity and a unifying national political ideology. One of the important reasons for the creation of new countries in Europe in the 19th century was the Napoleonic wars and the imperialism of various European leaders and monarchist families. Such countries as modern Italy and Germany were torn by the territories, which were part of other states.

In the first quarter of the 19th century, the Italian lands were divided. Italian self-identification did not exist. A resident of Venice considered himself a Venetian, and people of Florence considered themselves Tuscans. Italian nationalist forces set a goal to unite all Italian lands into one big Italy and create a national identity, Italian.

Various foundations were used to unite the Italian lands, some of the nationalists dreamed of the former greatness of the ancient Roman Empire, or the Papal State, while others pursued pragmatic economic goals. The most important role in the unification of Italy and the creation of Italian self-identity was played by Giuseppe Garibaldi, his Red Shirts and the Prime Minister of Sardinia, Cavour. The unification of Italy was completed by the Lateran Treaty in 1929, under Benito Mussolini, in which the Rome Question was resolved, and Rome became the capital of Italy, and the Vatican became an independent state.

The main problems faced by the united Italy, poverty and illiteracy of the rural population, as well as the lack of public perception of themselves as the Italians [10].

Today, the most important elements uniting the Italian people into one are the Italian language, common history and the Catholic Church. Today, the situation with Italian identity is not straightforward. Study conducted by (More in Common), "Attitudes towards National Identity, Immigration and Refugees in Italy", which was published in July 2018, showed that Italians today lack of strong national identity. Italians themselves do not feel a strong attachment to the history of Italy, which indicates weak patriotic feelings. One of the problems that hinder the creation of a common Italian identity is the strong attachment of individuals to their own families, which is more pronounced than in other European nations, as well as the feeling of many identities, which is caused by the social pattern of the historical development of Italy [11].

Germany has very similar problem. The kingdom of Prussia became the center around which the German lands became united. Under the leadership of Otto von Bismarck, Prussia conducted a number of military companies against Austria, Denmark and France, which contributed to the proclamation of the German Empire in 1871, and the creation of a common German identity. An important element in the creation of German identity was played by the German language and the mutual economic relations of the united German lands. An important role in the formation of German identity was played by the Prussian spirit of expansionism, militarism and imperialism. An important role in the formation of the German ideology was played by the "volkisch", ethno-national ideology, the unity of people formed by an identical language and historical fate [12].

As Bismarck himself expressed in relation to the creation of a common German state, it was created with the help of "Blood and Iron". The ideology of Pan-Germanism, on which the unification of Germany was based, was built on overcoming difficulties, hard motivation and pride in the achievements of its people. A new type of Germans was built around militarism and masculinity [13].

The unification of Germany and the creation of a common national identity enabled Germany, as a state, to play an important role in the geopolitical arena of the late 19th and early 20th centuries. The inevitable struggle for domination, imperialism, pushed Kaiser of Germany to the beginning of the World War I, on the side of other empires, with identical goals, such as the Austro-Hungary and Ottoman Empire. The loss in the World War I greatly influenced the further change of German identity, self-consciousness and ideology.

The Weimer Republic, which was peaceful, democratic and liberal, contradicted the ideological self-consciousness of the German people. The ideas of revanchist, neo-imperialism and cruel totalitarianism resulted in the creation of a new ideology, for the Germans, Nazism.

The Nazis faced the question of creating a new German identity, which was supposed to rally the German people around one goal, revenge for the loss in the First World War. The creation of a new German identity under the National Socialist Party was built around the racial superiority of the German people, 
the Aryan genetic theory of perfection, and the annexation of the territories of the neighboring countries inhabited by the German people. The Nazis used the term "Blood and soil" (germ. "Blut und Boden") as a fundamental pivot for the unification of the German people, based on their native land, saturated with German blood, identical culture and traditions [14].

The Bolsheviks and the Soviet government also created a new identity for the formation of "Soviet man" from different peoples and ethnic groups living in 15 republics of the USSR. The first thing that Soviet party officials began to do when forming a new Soviet identity was the formation of a new history that began in 1917, a complete break with the past, and an emphasis on the "bright future". An important task that, in the creation of the Soviet man, melted, it was to level the national, ethnic, mental and religious features of various peoples living in the USSR, as well as to create a system of common Soviet patriotism. Soviet identity was formed very difficult. Part of the peoples who inhabited the USSR was considered not loyal to Soviet power. Many nations did not recognize the Soviet power, and fought for their independence. The Soviet government resorted to the deportation of these peoples or conducted punitive operations.

The first thing that Soviet party officials began to do when forming a new Soviet identity was the formation of a new history that began in 1917, a complete break with the past, and an emphasis on the "bright future". An important task that, in the creation of the Soviet man, melted, it was to level the national, ethnic, mental and religious features of various peoples living in the USSR, as well as to create a system of common Soviet patriotism. It was very difficult to form Soviet identity. Part of the people who inhabited the USSR was considered not loyal to Soviet power. Many nations did not recognize the Soviet power, and fought for their independence. The Soviet government resorted to the deportation of these peoples or to punitive operations.

It is necessary to separate the two stages in the formation of Soviet identity, before 1945 and after, namely, after Western Ukraine and the Baltic republics were incorporated into the USSR. Further, a certain discourse was traced in the question of whether Russian culture should dominate among the Soviet people, or the culture in the USSR should be multicultural, and all the cultures of the peoples of the USSR should merge. As a result, the Soviet government was able to achieve certain results in the creation of Soviet identity [15].

\section{The Attempt of common European nation construction}

The formation of the European Union and the concept of European identity have taken a long historical path. The goal was economic cooperation, so that European countries would not start new wars, turned into a confederation of countries united by common economic, cultural, scientific and social goals. After the collapse of the socialist bloc, in the beginning of the 21st century, the European Union already included 28 states. The fact is, that once what, the founding fathers Robert Schumann and Jean Monnet, saw how the union of economic cooperation and the customs union has developed into a political confederation which began to play an important role in the geopolitical space.

After the fall of the socialist block in Europe, new countries appeared on the continent willing to join the economic union. In 2004, Poland, the Czech Republic, Slovakia, Hungary, Latvia, Lithuania, Estonia, Slovenia, Cyprus and Malta joined the European Union. In 2007, the EU was joined by Bulgaria and Romania. Thus, we see that many former socialist countries have joined the European Union. It is worth noting immediately that these states joined the Union, mostly for economic reasons. Their main goal was to obtain European loans for economic development, modernization and access to European markets.

The European Union, by the second decade of the 21st century, became a powerful economic and political bloc. European politicians in Brussels realized that nationalist views in the EU member states were not far off, and it was necessary to develop a universal European identity that could be opposed to the national egoism of the EU member states. Proponents of European identity emphasize on a common culture, history and Christianity.

The leaders of the European Union, since the eighties, began to form a European identity, building it out of the identities of different European nations. The culture of the European people is used to create jobs, economic goods, and a link in the creation of a European identity. Based on the creation of European identity, the leadership of the European Union in Brussels, is trying to create the concept of a common European people who would have European citizenship. Various interstate programs are being implemented for the formation of European civil consciousness. At the same time, introduction of Arab migrants who started arriving en masse in 2015 and resurgent nationalism in different European countries call into question the creation of a common European identity [16].

The European Union is still divided for those who are "for European identity", and for "those who are against it". Liberal, left and green parties advocate for a united Europe, and a common European identity. In the camp of euro skeptics, there are nationalist right-wing nationalist parties who consider the creation of a common European identity, an encroachment on the identity of their own people.

Here, immediately it is necessary to note two conflicts of political interests. On the one hand, the central European authority advocates, for the preservation of a united European Union, and the development 
of a common European identity, in order to strengthen its influence from Brussels, on all the countries of the European Community. On the other hand, they are opposed by nationalist parties and euro-skeptics who want to have full power in their states. Nationalist parties, in many countries of the European Union, are in favor of preserving the identity of their national identity.

\section{The common European identity and refugee's crisis}

Since 2015, in the Mediterranean region and Europe, the crisis began with refugees from African and Arab countries. Many believe that this crisis began in the fall of 2015 , but this is a misconception, since the problem has developed for many years, and the roots of this crisis were formed in the nineties of the XX century. The civil wars in central Africa led to a significant shift of the African population to the north of the African continent to Arab countries, mainly to Morocco and Libya.

In Morocco, African refugees lived in big cities and in refugee camps. In Libya, they also lived and worked in the country's oil industry. The authoritarian regime of Colonel Muammar Gaddafi, restrained African refugees from further migration to the north, through the Mediterranean Sea to Europe. After the beginning of the Arab Spring, the civil war ravaged Libya, after which African and Arab refugees and displaced people began to move north. Similarly, the wars in Iraq and Syria formed a large number of Muslim refugees who, through Turkey and the Balkans, relocated to the European Union [17]. The leaders of the European Union were not ready for this challenge. On one hand, the European society is based on liberal-democratic principles, which are dominated by the idea of respecting human rights and a tolerant attitude to foreign cultures and customs, and on the other hand, Muslim refugees from Africa and the Middle East brought with them their way of life. The social, ethnic and religious conflict is caused by the fact that the European society feels constrained by European democratic principles, while Muslim refugees feel protected by the same liberal principles of human rights. Here, we can see a direct clash of two civilizations, on the one hand European-Christian, and on the other hand Arab-Muslim.

Muslim migrants are starting to organize themselves, thereby gradually building their own state in the state, which has already become a pretext for the ethnic confrontation between the indigenous people of Europe and the refugees who have arrived. This is also used by nationalist parties in various EU member states who oppose the presence of their countries in the European Union. Thus, Europe enters an era of conflict, on ethnic, religious and cultural grounds, where the interests of the European Union government, nationalist organizations and political parties of various EU member states, and Muslim migrants and refugees collide.

Islam serves as a unifying element in the rallying of different nations. Islam binds them, in one way of life, to religious and cultural values. As mentioned, the Muslim "ummah", that is, the community, plays an important role in uniting all Muslims, regardless of where they are located. The Ummah says that all Muslims are brothers, regardless of other aspects, such as ethnicity or nationality. It is the concept of the Ummah that unites Muslims and mobilizes them for various actions, creating one large Muslim nation [18].

European society is experiencing a post-modern era, where neoliberalism liberates a person from religious prejudices, but at the same time it develops individualism and egoism in it. Religion plays a lesser role in the life of the citizens of the European Union, where atheism and hedonism are replacing religious values. European citizens living the postmodern philosophy are not able to resist the arrived Muslims who build the philosophy of their life on religious dogma, and act as one.

Conclusions. Against the background of an increase in the Muslim population of Europe, the leaders of the countries of the European Union are pessimistic. Their attitude towards liberalism, tolerance and the concept of a united Europe is lost.

At the heart of the emerging conflict, there are three groups of interests. On the one hand, there is the European Parliament and its bureaucracy, which lives on the existence of the European Union. On the other hand, there are leaders of states that disagree with the policies of the European Union in accepting Muslim settlers and resettling them in the countries of the European Union. Also, the nationalist parties of European countries, are offering a quick and radical solution to the issue of Muslim migrants, and use the crisis situation for their political benefits. And the third group is European Muslims, who unite into communes, live compactly in large European cities, and do not recognize the European way of life. A low birth rate among indigenous Europeans, an aging population, as well as a high birth rate among Muslim migrants, will further lead to a demographic change in Europe and an increase in the Muslim population on the continent. The clash between the European postmodern philosophy of life and Islamic modernity is manifested in the inability of the European model of building society to resist the classical Islamic model built on the dogmas of religion. 


\section{References:}

1. Hungtington P.S. The clash of civilizations? Foreign Affairs ; New York ; Summer 1993. C. 1-9. URL: http://www.columbia.edu/itc/sipa/S6800/courseworks/foreign_aff_huntington.pdf.

2. Бибикова О. Новые иммигранты и Европа: Конфрликт задач. Европейская безопасность: события, оценки, прогнозы. Выпуск 40 (56). Март 2016. С. 8-10. URL: https://cyberleninka.ru/article/v/ novye-immigranty-i-evropa-konflikt-zadach.

3. Oleinik V.I. The vertical and horizontal islamization of Western Europe in the context of migration crisis. Власть. Май 2016. С. 181-184. URL: https://cyberleninka.ru/article/v/ vertikalnaya-i-gorizontalnaya-islamizatsiya-zapadnoy-evropy-v-kontekste-migratsionnogo-krizisa.

4. Разливаев А.А. Мусульмане в Европе: препятствие на пути к цивилизационному компромиссу. Вестник ВГУ, Серия «Лингвистика и межкультурная коммуникация». Выпуск № 2. 2008. С. 236-243. URL: https://cyberleninka.ru/article/v/ musulmane-v-evrope-prepyatstviya-na-puti-k-tsivilizatsionnomu-kompromissu.

5. Larive M. A Crisis for the Ages. The European Union and the Migration Crisis. Miami-Florida European Union Center of Excellence. Том 15. Октябрь 2015. C. 1-17. URL: http://aei.pitt.edu/74531/1/Larive_ MigrationCrisis.pdf.

6. Collet E., Coz C. AFTER THE STORM. Learning from the EU response to the migration crisis. Migration policy institute. Июнь 2018. C. 1-54. URL: file:///C:/Users/\%D0\%90\%D0\%BB\%D0\%B5\%D0\%BA\%D1 $\% 81 \%$ D0\%B5\%D0\%B9/Downloads/EUCrisisResponse_FINALWEB.pdf.

7. Stacey A. The Concept of Ummah in Islam.02/04/2018. C. 1-3. URL: https://www.islamreligion.com/ pdf/en/the_concept_of_ummah_in_islam_11312_en.pdf.

8. Inaç H., Ūnal F. The Construction of National Identity in Modern Times: Theoretical Perspective. International Journal of Humanities and Social Science. Том 3. № 11. Червень 2013. C. 227.

9. Hobsbaum E.J. Nations and nationalism since 1780. Programme, myth, reality. New York. Cambridge University Press. Друге видання. 1990. С. 5-13.

10. Unifying Italy. URL: https://www.cheektowagak12.org/site/handlers/filedownload.ashx?moduleinstance id=1748\&dataid=2235\&FileName=Italian\%20Unification. pdf.

11. Attitudes towards National Identity, Immigration and Refugees in Italy/ [Dixon T., Hawkins S., Heijbroek L., Juan-Torres M., Demoures François-Xavier]. More in Common., 2018 C. 4-5. URL: $\quad$ https://www.thesocialchangeinitiative.org/wp-content/uploads/2018/07/Italy-EN-Final_Digital. compressed.pdf.

12. Сычева Н.А. Становление немецкой национальной внешнеполитической идеологии в XIX веке : автореф. дис. на здобуття наук. ступеня канд. іст. наук : спец. 07.00.03. «Загальна історія». Москва, 2006. URL: https://www.dissercat.com/content/stanovlenie-nemetskoi-natsionalnoivneshnepoliticheskoi-ideologii-v-xix-veke/read. C. 15.

13. Kastelberg K. German Nationalism and Identity During the Age of Unification. 2005. C. 13. URL: https://ysmithcpallen.com/sites/default/files/sites/all/documents/kastelberg_karl.pdf.

14. Trueman C.N. Blood and Soil. 2012. URL: https://www.historylearningsite.co.uk/nazi-germany/ blood-and-soil/.

15. Wojnowski Z. The Soviet people: national and supranational identities in the USSR after 1945. National papers, 2015. № 1. C. 1-7. URL: https://www.tandfonline.com/doi/full/10.1080/00905992.2014.95346 7\#aHR0cHM6Ly93d3cudGFuZGZvbmxpbmUuY29tL2RvaS9wZGYvMTAuMTA4MC8wMDkwNTk5Mi4 yMDE0Ljk1MzQ2Nz9uZWVkQWNjZXNzPXRydWVAQEAw C. 2- 3.

16. Tsaliki L. The construction of European identity and citizenship through cultural policy. European studies. Vol. 24. 2007. C. 158-159.

17. Сухов Н.В. Восстание в арабском мире: посевы и восходы. Миграционные процессы в Северной Африке в контексте арабского кризиса: только ли проблема Европы? Азия и Африка Сегодня. 6. 2016. С. 11-17.

18. Ислам в мировой политике в начале XXI века : учеб. пособие / под ред. Л.М. Ефимовой, М.А. Сапроновой ; [А.М. Ахунов, В.А. Ахмадуллин, Р.И. Беккин и др.] ; Моск. гос. ин-т междунар. отношений (ун-т) М-ва иностр. дел Рос. Федерации, каф. востоковедения. Москва : МГИМО-Университет, 2016. С. 7-10. 